\title{
HOMOGENEOUS CHEMILUMINESCENT IMMUNOASSAY BASED ON COMPLEMENT MEDIATED HEMOLYSIS
}

\author{
YOSHIRO TATSU, SOICHIRO YAMAMURA, and SUSUMU YOSHIKAWA \\ Government Industrial Research Institute, Osaka, \\ Midorigaoka, Ikeda, Osaka 563, Japan
}

\begin{abstract}
Human serum albumin (HSA) was determined by the homogeneous chemiluminescent immunoassay. The assay was performed by two methods, complement fixation method and competitive direct hemolysis method. After the complement mediated hemolysis of red blood cells, the chemiluminescence of luminol catalyzed by leaked hemoglobin was measured homogeneously. The sensitivities of HSA were 0.25 $\mu \mathrm{g} / \mathrm{ml}$ and $0.1 \mu \mathrm{g} / \mathrm{ml}$, respectively but the latter method was convenient for the assay.
\end{abstract}

Key words homogeneous, chemiluminescence, immunoassay, complement

Hemoglobin, a heme-protein, is encapsulated in red blood cells with high concentration and is one of the potent catalysts for chemiluminescent reaction of luminol and hydrogen peroxide. We found out that the non-hemolyzed red blood cells themselves showed no catalytic chemiluminescence, while the hemolyzed cells could do efficiently. Therefore, the extent of hemolysis could be measured without separating hemolyzed and non-hemolyzed cells. We combined this behavior with the complement mediated hemolysis reaction and developed it as a new homogeneous immunoassay [1,2], where complement, antibody, and hapten on carrier protein were assayed. The present report describes the assay of high weight molecule, HSA, by two kinds of measurement; the complement fixation method [3] and the competitive direct hemolysis method. In the former method, the remained complement activity after complement consumption by antigen-antibody complex was measured using commercially available hemolysin sensitized sheep red blood cells (EA). Antigen-modified sheep red blood cells were used in the latter method and antibody was competitively reacted with antigen. The cell bound with antibody was hemolyzed by complement.

\section{EXPERIMENTAL}

Apparatus and reagents All chemiluminescent measurements were carried out by the photon counting method with a Hamamatsu R-2757 photomultiplier tube and a Hamamatsu C-2550 signal processor. Rabbit anti human albumin and lyophilized guinea pig complement were obtained from Seikagaku-kogyo and Handai-biken. Sheep red blood cells or EA were obtained from Ishizu-seiyaku. Human serum albumin was obtained from Nakarai tesque. Albumin modified cells were prepared as described previously [2]. Buffer used was veronal buffered saline at pH7.4 containing $0.1 \%$ gelatin, $0.5 \mathrm{mM}$ of $\mathrm{CaCl}_{2}$, and $0.15 \mathrm{mM}$ of $\mathrm{MgCl}_{2}\left(\mathrm{GVB}^{2+}\right)$. All the other chemicals were of reagent grade.

Assay procedure In the complement fixation method, standard solution of HSA $(10 \mu 1)$ was mixed with 160 -fold diluted anti-HSA $(10 \mu \mathrm{l})$ and complement $(12.5 \mu 1,0.76 \mathrm{CH} 50 / \mathrm{ml})$ and incubated at $37^{\circ} \mathrm{C}$ for $60 \mathrm{~min}$. After the incubation, EA $\left(5 \times 10^{8} / \mathrm{ml}, 5 \mu 1\right)$ was added and the mixture was incubated at $37^{\circ} \mathrm{C}$ for $60 \mathrm{~min}$. After the immunochemical reaction, $37.5 \mu \mathrm{l}$ of GVB was added and kept at $4^{\circ} \mathrm{C}$ until chemiluminescent measurement. Chemiluminescent reaction was done by adding each $50 \mu 1$ of luminol $(1 \mathrm{mM})$ and $\mathrm{H}_{2} \mathrm{O}_{2}(5 \mathrm{mM})$. In the competitive method, standard solution of HSA $(7.5 \mu \mathrm{l})$ was mixed with 320 -fold diluted anti-HSA (10 $\mu 1)$ and albumin modified cells $\left(2.5 \times 10^{8} / \mathrm{ml}, 10 \mu \mathrm{l}\right)$ and incubated at $37^{\circ} \mathrm{C}$ for $15 \mathrm{~min}$. After the incubation, complement $(10 \mu 1,1.16 \mathrm{CH} 50 / \mathrm{ml})$ was added and the mixture was incubated at 


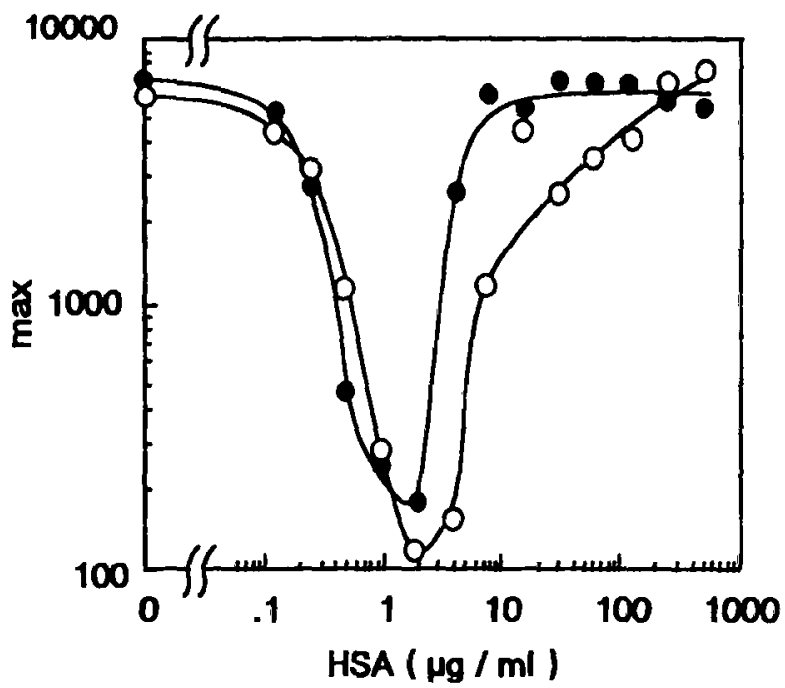

Fig. 1. Complement fixation method for HSA. Anti-HSA was 160 -fold (•), and 80-fold (O) diluted.

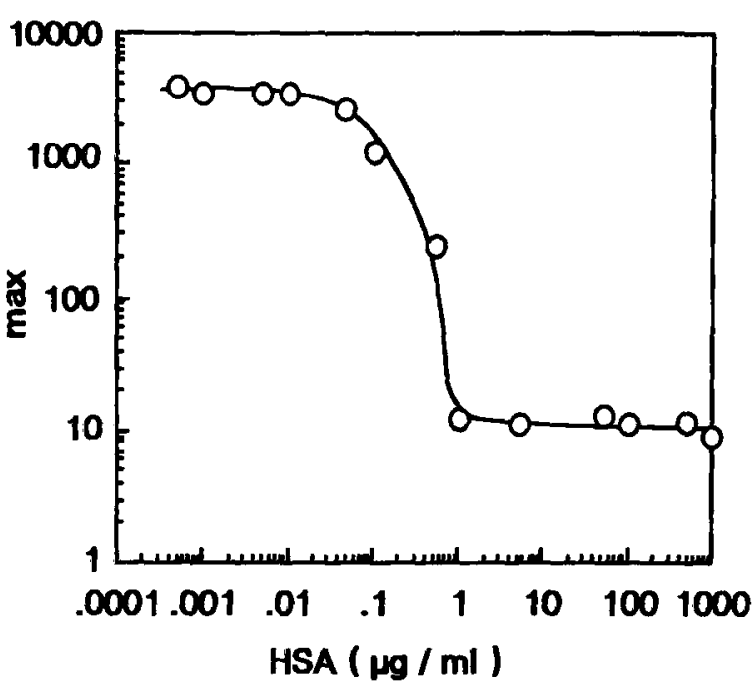

Fig. 2. Competitive direct hemolysis method for HSA.

$37^{\circ} \mathrm{C}$ for $60 \mathrm{~min}$, followed by the same procedure of the previous method.

\section{RESULTS AND DISCUSSION}

Complement fixation method Figure 1 shows the standard curve of HSA. The ordinate is the maximum value of chemiluminescence during the measurement. The minimum in the chemiluminescence was observed at $1 \mu \mathrm{g} / \mathrm{ml}$ of HSA. At lower or higher concentration, chemiluminescence reached to the saturation. Complement is activated by the antigen-bound antibodies where at least two IgG molecules are neighboring with each other. At higher concentration of HSA, the number of antibody bound to one HSA molecule is smaller and complement is activated mainly by EA. At lower concentration of HSA, a little number of the complex is formed and complement is activated mainly by EA, also. The optimum concentration for inhibition of chemiluminescence would be, therefore, observed. Since the standard curve has minimum point, wide range of HSA could not be determined. Only the antigen or antibody excess zone could be applicable for the assay.

Competitive direct hemolysis method Standard curve by this method has no minimum point as shown in Fig. 2. At higher concentration of HSA, the chemiluminescence was not observed. With diluting HSA, the chemiluminescence increased and saturated. Although the curve is not in first order linearity, the response would be better for the determination of HSA than that of the curve in Fig. 1. In this method, anti-HSA is competitively activated both with free HSA and HSA bound to SRBC. In contrast to the previous method, no unbound anti-HSA antibody is remained after the reaction. Constant amount of antigen-antibody binding is formed and no minimum point would be, therefore, observed. The sensitivity of HSA was $0.1 \mu \mathrm{g} / \mathrm{ml}$, which was almost the same range as previous method. To obtain the linear standard curve and higher sensitivity, optimization of the concentration of antibody, complement, and SRBC and the amount of bound HSA on SRBC is needed.

HSA was determined down to sub micro grams by the both methods. The factor for sensitivity was governed mainly by immunochemical reaction, because the measurement of chemiluminescence was sensitive. The optimization of the reaction condition would improve the sensitivity.

\section{REFERENCES}

1. Y. Tatsu and S. Yoshikawa, Chem. Lett., 1990, 1467.

2. Y. Tatsu and S. Yoshikawa, Anal. Chem., 62, 2103 (1990).

3. E. Wasserman and L. Levine, J. Immunol., 87, 290 (1961). 